\title{
The ordinary of mass chants and the sequences
}

\author{
David Hiley
}

Notes p. 78

\author{
Several writers - most notable among \\ the recent ones being Max Lütolf, Rudolf \\ Flotzinger and Edward Roesner ${ }^{2}$ - have \\ commented on the choice of liturgical chants \\ set in the additions to the main layer of \\ Parisian polyphony in $W 1$. The point of such \\ comment is that by tracing concordances for \\ those liturgical chants a clearer idea may \\ be gained of the affiliations of W1 among \\ the chant traditions of Britain and North \\ France. The additions to $W 1$ are more useful \\ for this purpose than the main body of \\ organa. The latter are settings of chants \\ which were for the most part very widely \\ known. Relatively few of them are unusual \\ enough to permit speculation about the \\ church for which w1 was compiled, or about \\ the liturgical use to which it most nearly \\ corresponds. So far as the organa are con- \\ -cerned, I do not feel that much advance \\ can be made upon the careful discussion in \\ Professor Roesner's article. \\ I propose, however, to enlarge the \\ discussion of two genres of chant which are \\ found among the additions to W1: the ordinary \\ of mass chants and the sequences. There are \\ two good reasons for concentrating upon \\ these chants. Firstly, since they amount to \\ 37 out of the 59 added pieces (I omit the \\ additions to fascicle $10^{2}$, they constitute \\ a majority: there are eight ordinary of mass \\ items among the additions to fascicles 3,8 \\ and 9 , and in fascicle 11 there are fifteen \\ ordinary of mass items and fourteen sequences. \\ Secondly, they have been more thoroughly \\ catalogued than any of the other genres: we \\ have the catalogues of Melnicki, Bosse, \\ Thannabaur and Schildbach for ordinary of \\ mass chants, and my own catalogue of \\ ordinary of mass chants in North France \\ Britain and Sicily; and the volumes of \\ sequence texts in Analecta Liturgica and \\ Analecta Hymica for sequences. ${ }^{3}$ \\ Because of the two responsories for \\ St.Andrew added to fascicle 3 (ff.xxii/18v- \\ xxiii-19v), and because $W 1$ was at St.Andrews \\ by the early 14 th century, St.Andrews is \\ the most likely place for which the manu- \\ -script might have been destined. But no \\ gradual, antiphoner or troper has survived \\ from St.Andrews. So this part of our joint \\ article cannot 'locate' W1 geographically. \\ It can only suggest a place for it among \\ several interrelated liturgical traditions. \\ What follows is a study of repertories, \\ which does not concern itself so much with \\ the assignment of individual chants to \\ specific places of origin as with the \\ interplay of groups of pieces favoured in \\ different areas or among different groups \\ of churches. That $w 1$ can be assigned more \\ or less confidently to mid-13th-century \\ $\mathrm{St}$.Andrews is something which does not
}

materially affect the study: we could proceed even if we knew nothing about the likely history of the manuscript.

I

\section{ORDINARY OF MASS CHANTS}

I have already published a diagram and a brief discussion of the interrelationships between North French and British collections of ordinary of mass melodies and tropes. ${ }^{4}$ Taking a broad view, one may say that whereas up to the beginning of the 13th century British books (that is the Winchester tropers, the gradual of Christchurch, Canterbury, and the two St.Albans books ${ }^{5}$ ) show a rather diffuse set of affiliations with a variety of North French traditions, those of the 13th century and later display connections more with Parisian collections than with any other continental ones. Lacunae make the situation less than ideally clear: we have no Paris collections prior to the 13 th century; and no collections at all from such centres as Amiens, and many English secular cathedrals. Surviving Rouen collections ${ }^{6}$ are late and so individual as to make one wonder if they have not been revised since the 13th century. But with all due reservation the evidence seems to point clearly enough in one direction.

I discuss in turn those groups of books which form the requisite background for examination of $W 1$.

\section{Parisian collections}

Among the various interrelated tradi-tions present in Paris itself, that of the cathedral of Notre Dame is followed in a majority of surviving sources. ${ }^{7}$ The ordinary of mass pieces in these books are not always exactly the same, but the differences are few, and unimportant in the present context. The following troped items are found (the numbering system established in the catalogues of Melnicki, etc., is followed here $)^{8}$ : Kyrie 16 tr.1 Orbis factor, 18 tr.1 Cunctipotens, $48 \mathrm{tr} .1$ Kyrie fons bonitatis, $48 \mathrm{tr} .9$ Kyrie pater eterne, 58 tr.1 Pater cuncta, 102 tr.1 Clemens rector; Gloria 23 tr.104 Spiritus et alme; Agnus 226 tr.105 Qui sedes. And, but very rarely, Sanctus 49 tr. 151 Perpetuo numine and tr.159 Plebs tibi mente.

Surviving books following the use of St.Victor ${ }^{9}$ do not usually have any troped items at all. It is noteworthy that although their ordinary of mass collections are small they are nevertheless quite distinct from 
those of the main Paris city tradition by including Kyrie 57 and omitting Kyries 102 and 155, apart from other idiosyncracies. More interesting collections are found on the periphery of the Paris traditions. Bari, S.Nicola, 88 is from the chapel of the Angevin rulers of South Italy, whose use was originally imported from Paris. ${ }^{10}$ After an uninteresting selection of Kyries there appear in this manuscript several Sanctus and Agnus not found in the more common Paris books: Sanctus 116, 177, 202 and 203; Agnus $34,100,114,220$ and 267 .

An even more interesting complement to Paris use appears in Assisi, Bibl. Comunale, 695. 11 The various main sections of this manuscript were all written by the same hand (or hands, if we assume the notator different from the text scribe), but from a variety of exemplars. In the first section of the manu-script we have an ordinary of mass collection enclosing farced lessons, the Genealogies, Exultet and Laudes Regiae, etc. The Laudes are in a Reims version; there are two melodies for o redemptor sume carmen, the first being labelled "secundum usum Parisi-ensis ecclesie". The rich collection of ordinary of mass chants has no parallel among regular paris books, although it includes practically everything found in them. But since surviving Reims collections for the ordinary of mass (in Reims, Bibl. Municipale, 224 and 266) are so meagre, it is impossible to say whether Assisi 695 has Reims or Paris items without studying variant readings in these and a wide range of other sources. This is not yet accomplished.

In Assisi 695 there follows the first of three consecutive collections of sequen-ces. This is definitely an amalgam of Reims and Paris, Reims sequences being easily detectable through concordances, with Paris versions of some common pieces becoming apparent when variant readings are compared.12 The second and third collections are overwhel-mingly composed of parisian sequences, though a few strangers among the regular paris books are again to be found, and numerous unusual melodies for well-known texts.

Looking for a personage who might have commissioned a book containing such a mixture of Reims and Paris material, de Manteyer lighted upon Renaud de Corbeil, Archdeacon of Reims, elected Bishop of Paris in 1250, who died in 1268; and this hypothesis about the origin of the collection has remained the most plausible to date. Unfortunately. illuminated initials which might have helped to localize and date the book have been excised. Of all books connected with Paris, indeed of all continental books, Assisi 695 has the most interesting links with British manuscripts and with $W 1$, and it is regret-table that it appears rather exceptional among 13 th-century North French manuscripts and that its origin is still somewhat mysterious.

\section{Sarum books}

Sarum collections, which appear from the 13th century onward (the earliest appears to be that in Manchester, John Rylands Lib. lat.24) contain several items not known in England before: Kyrie 67, Gloria 9 and 23 , Sanctus $41,82,130,177$, and Agnus 55, 101, 217 (late Sarum books only); and tr.2 Kyrie rex splendens for Kyrie 24 , and tr.104 Spiritus et alme for Gloria 23. Not all of these are unique to Sarum of course. For instance, Kypie rex splendens appears in 12th-century Norman (French, not English) books, and is also found in the Worcester gradual (Worcester, Chapter Lib., F160, first half of the 13 th century). Sanctus 177 was well known outside France, but its only English-French point of contact is Assisi 695. Agnus 101 appears patchily in France. And Gloria 23 tr. 104 was very well known. This leaves six melodies (a not insig-nificant proportion) as distinctively Sarum.

One special collection, London, British Lib., Add.17001, adds a few pieces from outside this fairly stable nucleus: Kyrie 14, 95, Gloria 12, Agnus 34, 114. Kyrie 14 is known otherwise on $1 \mathrm{y}$ from Oxford, Bodleian Lib., Lat.1it.b.5 (York diocese); Gloria 12 and Agnus 114 are common enough in England but are not to be found in any other Sarum collection. Agnus 34 has only two English concordances: Shrewsbury School XXX (15thcentury collection added to a late-12th century book, from Haughmond) and oxford Lat.lit.b. 5 again; and two significant foreign concordances: Paris, Bibl. Nationale, lat. 904 (Rouen) and Bari 88. Kyrie 95 is not otherwise known in England at all, but is to be found in Paris, Bibl. Nationale, lat.830 (Paris) and the two Rouen books Paris 905 and 904 . These continental concordances are not, of course, sure evidence of contact between York and Paris or Rouen. The melodies are also to be found in other late sources; we are less wellinformed about continental 15 th-century collections than about 13 th-century ones, and a wider survey of these late books is necessary before the position of London 17001 is as clear among them as it is among English sources.

\section{English non-Sarum books}

Several sources stand mid-way between the older Benedictine traditions (which do not impinge upon the repertory in $W 1$ ), and the new 13th-century repertories of which Sarum books are one example. These include Worcester F160 and London, British Lib., Harley 3965 (from Hereford): they are quite distinct from each other and from Sarum. Two others are less so: Oxford, Bodleian Lib., Lyell 9 (possibly from the Augustinian house of Breamore; Hants.) and Oxford, University College, 148 (from Chichester). Paris, Bibl. de l'Arsenal, 135 is considerably different. Although following on from, and copied in the same hand as, a Sarum noted missal, it is in no sense a Sarum collection. ${ }^{13}$ It has more troped items than any other 13 th-century English book, and so, not surprisingly, it scores the highest number of concordances with, among others, Paris books, particularly with the largest collection Assisi 695. What is more significant is that it actually discriminates in favour of those pieces, omitting several melodies and tropes well established in Sarum and other English uses.

The ordinary of mass collection in Arsenal 135 has been somewhat unlucky, in that Melnicki catalogued two of its Kyries into Parma, Bibl.Palatina, 98, 14 Bosse's Gloria catalogue did not use the manuscript, and Schildbach's Agnus catalogue omitted three of its tropes.15 of these omissions the Gloria melody and one of the Agnus tropes have concordances in $W 1$.

The ninth to fifteenth Kyries in

Arsenal 135 are for the Blessed Virgin Mary. There follow three other troped Kyries, bringing the total to eighteen. Then comes 
a melody without trope, then the text (without trope) for five more melodies whose music was never entered. There are seven Glorias, the sixth being also in W1 (albeit with significant variants in the melody), and the seventh having the spiritus et alme trope for the B.V.M. Fourteen troped Sanctus follow, of which the eighth to the twelfth are Marian; then come six untroped and one more troped Sanctus. There are seventeen Agnus Dei, and all but the last two are troped. The ninth to the fifteenth have Marian texts. On f.300v is another troped Kyrie. If we exclude the Glorias (Glorias were very rarely sung with tropes from the 13 th century onwards, except for the spiritus et alme piece) there are in all 58 items in this collection, of which no less than 49 have tropes. This, and the large blocks of chants for the B.V.M., make Arsenal 135 unique among English sources, and it is tantalizing that, as with Assisi 695 , its origins are obscure. I follow Christopher Hohler 16 in believing it likely to have been intended for a London church.

Associated rather distantly with Arsenal 135, with each other, and with Jondon 17001, but not with other English books, are two collections from York: Oxford Lat.lit.b.5 (from East Drayton, Notts.), whose literary text agrees with York secular use, and which is our only surviving witness to the York ordinary of mass repertory; and Cambridge, St.John's College, D.27, a 15thcentury ordinal from St.Mary's Abbey, York. The unusual pieces in these manuscripts are the following:

Oxford Lat.1it.b.5 - Kyrie 14; Gloria 24 ; Sanctus 32 tr.31 Clangat hodie, 49 tr.119 o mater dei, 116 tr.238 Voce vita; Agnus 34,114 tr. 36 Factus homo.

Cambridge D.27 - Kyrie 39 tr.4 Lux et gloria, 47 tr.(8) Kyrie virgine: Iux, 48 tr.3 Kyrie virginitatis amator, $70 \mathrm{tr} .(7)$ Conditor Marie, Kyrie trope Kyrie pater almel7; Sanctus $32 \operatorname{tr} .238$ Voce vita; Agnus $114 \operatorname{tr} .36$ Factus homo, $136 \operatorname{tr} .53$ Lux angelorum.

The combinations sanctus $32 \mathrm{tr} .31$ and $49 \mathrm{tr}$. 119 are unique to Oxford Lat.lit.b.5.

Gloria 24 was known at St.Victor, Paris, and a few other French centres. Kyrie 14 and Agnus 34 we have seen above in London 17001 , Bari 88 and Rouen. Sanctus $116 \mathrm{tr}$. 238 is added to Assisi 695 in two-voice polyphony. Agnus $114 \mathrm{tr} .36$ is an important and interesting case, found elsewhere in Cambridge D.27 and Assisi 695 - it is one of very few significant links with the St.Mary's book.

Cambridge D. 27 is altogether more indi-vidual. It has two unique Kyrie tropes (47 tr. (8) and Kyrie pater alme); Kyrie 39 tr. 4 and 48 tr. 3 found in Arsenal 135; and Kyrie 70 tr. (7) - these last three all to be found in W1. The combination Sanctus 32 tr.238 is known otherwise only from Arsenal 135. Unfortunately the witness of Cambridge D.27 is marred by 1 acunae. At the beginning of the book come the Sanctus and Agnus, all that remains of what would undoubtedly have been a complete collection of ordinary of mass chants. But in the ordinal, Kyries and the Gloria with trope spiritus et alme are specified in some detail for masses of the Blessed Virgin Mary; not, however, Sanctus and Agnus. 18
The collections in W1

After this rapid survey of Parisian and English collections of ordinary chants, I now give concordance tables for the melodies and tropes in W1. Table 1 (see over) covers fascicles 3,8 and 9 . To the French sources already cited I have added some others to broaden the picture so far presented. Several of the books mentioned above are defective, in that they lack Sanctus and Agnus collections, and so they do not appear on Table 1 . The import of W1's concordances is clear enough. It is related to Bari 88 and Assisi 695 more than to the more usual paris collections. Highest scorer overall is Arsenal 135. It may be noted that the tropes are decisive, since six of the melodies are long established in North France and England, five of them being in regular Paris books.

I should interpret this to mean that this part of W1's collection belongs to a relatively new (i.e. 13th-century) English tradition which is in some sort of contact with Parisian repertories.

The evidence of fascicle 11 is more difficult to evaluate, since this collection (and also the pieces added at the end of fascicle $10^{2}$ ) are designed for services in honour of the B.V.M., whether a weekly Saturday mass (as seems possible for fascicle 11 , since its sequences seem to some extent to be intended for different seasons of the church year) or for a daily commemoration during the octave of a major feast such as the Assumption (as seems possible for the fascicle 10 cycles). From this fact we should expect to find concordances with the Marian pieces in Arsenal 135 and Cambridge D.27, which have special provision for such litur-gical occasions.

Table 2 sets out concordances for the Kyries and Gloria, for which a larger spread of sources is available than for the Sanctus and Agnus.

Neither the Paris nor Sarum books score very highly here. W1 has none of the pieces which, I hazarded above, might have originated with Sarum use in the early 13 th century. (This was true for the Sanctus and Agnus in Table 1 as well.) Arsenal 135 has all the melodies again, but only three of the tropes. It is Cambridge D.27, with five of the seven Kyrie tropes, which has most concordances.

Finally, in Table $3 \mathrm{I}$ give concordances for the Sanctus and Agnus in fascicle 11. This time, Cambridge D.27's chants are not presented in the section of the ordinal especially for Lady masses, but it still scores well; as does the other York book. The Bari, Rouen books and Arsenal 135 have all the melodies.

\section{Conclusions}

The only English sources of Sanctus and Agnus tropes from the 13 th century onward are Worcester F160, Arsenal 135, Oxford Lat.1it.b.5, Cambridge D. 27 and $W 1$. The only substantial English collections of ordinary of mass chants for the Blessed Virgin Mary are in Arsenal 135, Cambridge D. 27 (Kyries and Gloria only) and 11 . And it is with these limiting factors in mind that we have to assess the evidence presented above. Statistically, Arsenal 135 has the outstanding number of concordances with $W 1$ : al1 the melodies and 13 of the 22 tropes. Although Oxford Lat.lit.b.5 has some tropes which are in $W 1$ but not in Arsenal 135, the connection with $W 1$ is compromised in these cases by concordances with Assisi 695. This leaves only Cambridge D.27 as a serious rival to Arsenal 135 , since it has three 
TABLE 1

ORDINARY OF MASS ITEMS, W1 FASCICLES 3,8 AND 9

$x$ signifies melody concordance

$\checkmark$ signifies trope concordance

* signifies an addition to the manuscript

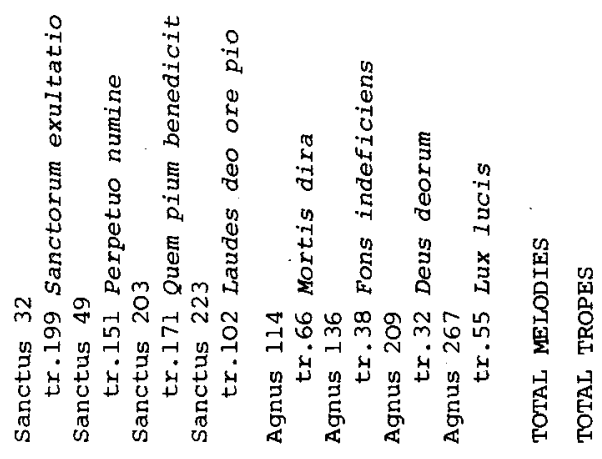

Durham Univ.Lib. Cosin VV6 (Christch. Canterbury, late 11th c.) London B.L. Royal 2.B.IV (St.Albans, late 12th c.) worcester Chapter Lib. F.160 (Worcester, mid 13th c.) Paris Bibl. de I'Arsenal 135 (?London, late 13th c.) Shrewsbury School XXX (Haughmond; 15th c.) Oxford Bodleian Lib. Lat.lat.b.5 (York dioc., 15th c.) Cambridge St.John's Coll. D.27 (St.Mary's York, 15th c.) Manchester John Rylands Lib. lat.24 (Sarum, mid 13th c.) Oxford Bodleian Lib. Rawl:lit.d.3 (Sarum, mid 13th c.) Bologna Bibl.Universitaria 2565 (Sarum, late 13th c.) Cambridge Univ.Lib. Add.710 (Sarum, early 14th c.) Parma Bibl.Palatina 98 (Sarum, late 14 th c.) London B.L. Lansdowne 462 (Sarum, late 14th c.) London B.L. Add.17001 (Sarum, late 14th C.) London B.L. Royal 8.C.XIII (?Normandy, llth c.) Paris B.N. lat. 10508 (St.Evroult, 12th c.) Rouen Bibl. Mun. 276 (St.Ouen Rouen, 13th c. - text inc. only) Paris B.N. lat.905 (Rouen Cathedral, 15th c.) Paris B.N. lat.904 (Rouen Cathedral, 15th c.) Limoges Bibl.Mun. 2 (Fontévrault, 14th c.) Arras Bibl.Mun. 444 (St.Vaast Arras, late 13th c.) Laon Bibl.Mun. 263 (Laon, late 12th c.) Paris B.N. lat.13252 (St.Magloire Paris, 11th c.) Paris B.N. lat.1107 (St.Denis, late 13th c.) Paris B.N. lat.830 (Paris, late 13th c.) London B.L. Add.38723 (Paris, late 13th C.) Paris B.N. lat.1112 (Paris, mid 13th c.) Paris B.N. lat.861 (Paris, late 13th c.) London B.L. Add.16905 (Paris, late 13th c.) Paris B.N. lat.14452 (St.Victor Paris, mid 13th c.) Rouen Bibl.Mun. 249 (St.Laurent Eu, Victorine, 14th c.) Bari San Nicola 85 (Bari, 14th C.) Bari San Nicola 88 (Bari, late 13th c.) Assisi Bibl.Comunale 695 (?Paris, late 13th c.)

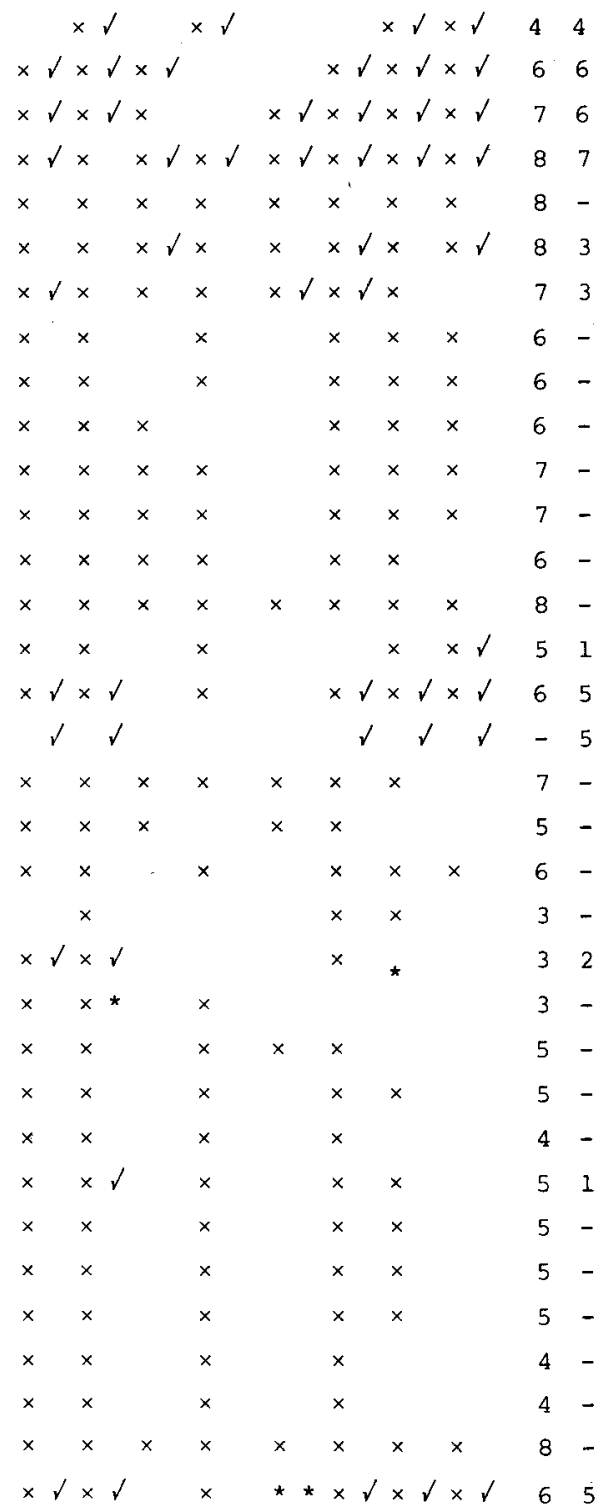


$x$ signifies melody concordance

$\checkmark$ signifies trope concordance

* signifies an addition to the manuscript

(see Table 1 for date and provenance of mss. not given here)

Oxford Bodleian Lib. Bodley 775 (Winchester, late llth c. supplement) Durham Univ.Lib. Cosin Vv6

Oxford Bodleian Lib. Laud misc.358 (St.Albans, late 12th c.)

London B.L. Royal 2.B.IV

Shrewsbury School XXX (Haughmond, late 12th c.)

London B.L. Cotton Caligula A.XIV (?Bristol, 12-13th c.)

Worcester Chapter Lib. F.160

Oxford Bodleian Lib. Lyell 9 (Breamore, late 13th c.)

Paris Bibl. de l'Arsenal 135

Oxford University Coll. 148 (Chichester, late 13th c.)

London B.L. Harley 3965 (Hereford, 15th c.)

oxford Bodleian Lib. Lat.lit.b.5

Cambriage St.John's Coll. D.27

Manchester John Rylands Lib. lat. 24; Bologna Bibl. Universitaria 2565

oxford Bodleian Lib. Rawl.lit.d.3; Parma Bibl.Palatina 98; London B.L. Lansdowne 462; London B.L. Add. 17001

Cambridge Univ.Lib. Add. 710

London B.L. Royal 8.C.XIII; Paris B.N. lat. 10508

Rouen Bibl. Mun. 276

Paris B.N. lat. 905

Paris B.N. lat. 904

Limoges Bibl. Mun. 2

Arras Bibl.Mun. 444

Laon Bibl.Mun. 263

Paris B.N. lat.13252

Paris B.N. lat. 1107

Paris B.N. Iat.830; London B.L. Add.38723, 16905

Paris B.N. lat.1112, 861

Paris B.N. lat.14452; Rouen Bibl.Mun. 249

Bristol Central Lib. 2 (St.Augustine's Bristol, 14th c.)

Bari San Nicola 85

Bari San Nicola 88

Assisi Bibl. Comunale 695 
TABLE 3

SANCTUS AND AGNUS, W1 FASCICLE 11

\section{$\times$ signifies melody concordance \\ $\checkmark$ signifies trope concordance \\ * signifies an addition to the manuscript}

(see Table 1 for date and provenance of mss.)

Durham Univ.Lib, Cosin vv6

London B.L. Royal 2.B.IV

worcester Chapter Lib. F.160

Paris Bibl. de L'Arsenal 135

Shrewsbury School Xxx (Haughmond, 15th c.)

oxford Bodleian Lib. Lat.lit.b.5

Cambridge St.John's Coll. D.27

Manchester John Ryland's Lib. lat.24; Oxford Bodleian Lib. Rawl.lit.d.3

Bologna Bibl. Universitaria 2565; Cambridge Univ.Lib. Add.710; Parma BibI. Palatina 98; London B.L. Lansdowne 462

London B.I. Add.17001

London B.I. Royal 8.C.XIII; Paris B.N. lat.10508; Rouen Bibl. Mun. 276

Paris B.N. lat. 905

Paris B.N. lat.904

Limoges Bibl.Mun. 2

Arras Bibl. Mun, 444

Laon Bibl. Mun. 263

Paris B.N. lat.13252

Paris B.N. lat.1107

Paris B.N. lat.830; London B.L. Add. 38723; Paris B.N. lat.1112 Paris B.N. lat.871; London B.I. Add.16905

Paris B.N. lat.14452; Roven Bibl.Mun. 249

Bari San Nicola 85

Bari San Nicola 88

Assisi Bibl, Comunale 695
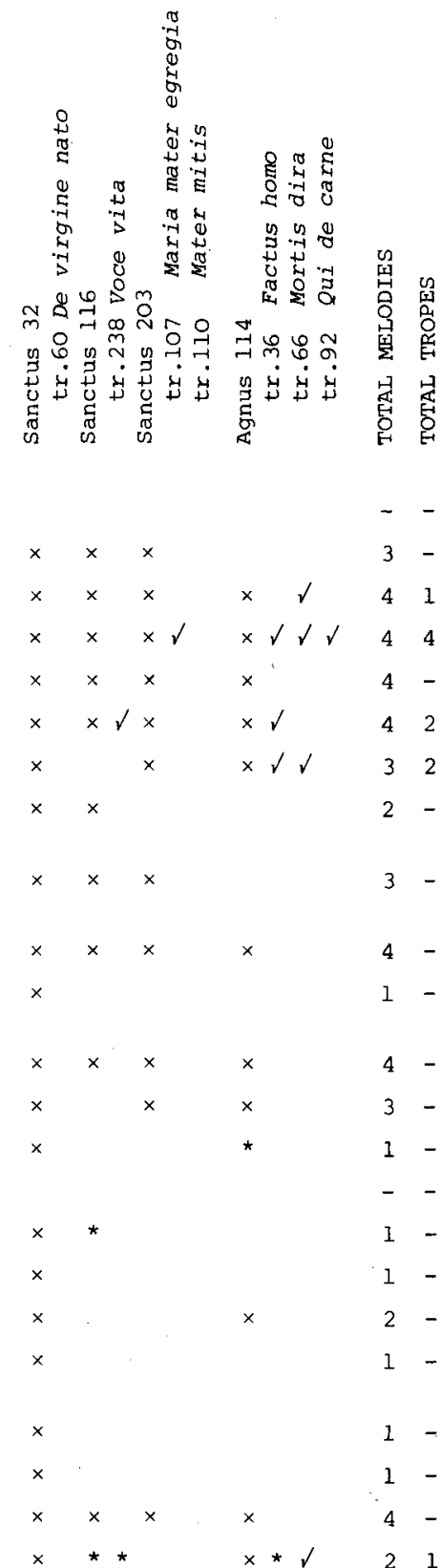
Kyrie tropes concordant with w1 which are not in Arsenal 135.

But whether $W 1$ is related more to Arsenal 135 or to Cambridge D.27, all three books, together with oxford Lat.1it. b.5, Assisi 695 and Bari 88 , should by virtue of their concordances be seen as a group, standing together against all other sources. They are a witness to new enterprise in the composition of ordinary of mass chants in the 13 th century, some of it directed specifically towards the increasingly popular masses for the B.V.M. There are of course $13 \mathrm{th}$-century manu-scripts from other parts of Europe telling the same tale: but these six sources form one wing of the new movement. If $W 1$ were written at $\mathrm{St}$. Andrews, then the wing would cover the most important centres on the way from scotland to Paris. ( If W1 were prepared in the south of England, say, oxford or London, then the concordances with Cambridge D.27, from St.Mary's, York, would be more unexpected, although the net effect would be to make Cambridge D. 27 seem more dependent on southern initiative.) The picture is at least plausible. And in conclusion it may be noted that the additions to fascicles 3,8 and 9 fit the picture just as well as the ordinary of mass items in fascicle 11 .

I I

\section{SEQUENCES}

\section{Concordances}

The 17 melodies and 22 tropes for the ordinary of mass in $W 1$ constitute a group whose size is at the lower limit of what can be discussed sensibly as a repertory. If a repertory is too small, single pieces begin to affect disproportionately the assessment of concordance patterns. That the necessary number of items is not present in the 14 sequences in $W 119$ is shown quite clearly by the totals of concordances in Table 4. Three of the sequences are unica; of the remaining eleven, no less than nine are present in five sources, and two more sources can muster eight concordances. Since these sources are spread across both England and North France, the simple counting of concordances is clearly insufficient for deciding the affiliations of W1. This is emphasized by the fact that Oxford Lat.lit.b.5, London 37519 and the Evreux missal of 1497 have exactly the same nine concordances, despite the fact that there is no discernible direct link between any of those three uses. In fact, with the exception of Virgo parens, all the sequences in w1 which are not unica are known from both English and French sources. At first glance, Paranymphus salutat virginem may suggest a continental interest on W1's part, but in fact the evidence points the other way: most continental sources known to me (to those on Table 4 may be added Aachen, Dombibl. 12 and Paris, Bibl. Nationale, iat.10502) have a melody different from that in W1. The only sources known to me with the same melody as W1 are Reims, Bibl.Municipale, 285 and 'Wor-cester Fragment' XXX (folios c-c verso, with a polyphonic setting different from W1). Paris, Bibl. de l'Arsenal (from ?London - its sequentiary, like its kyriale, is not a Sarum collection) does know the more usual continental melody, using it for Gabrieli colesti nuncio, which reworks material from the Paranymphus text. So Virgo parens, and to some extent Paranymphus, suggest that W1 is British.

In a collection of this small size it is a little surprising to find three unica; and it is also somewhat unexpected that three contrafacta of older sequences should appear (Virgini Marie zaudes from Victime paschali laudes, Laudes Christo decantemus from Laudes crucis attollamus, and Reginarum dominum from Epiphaniam domino). It seems possible that the compiler of this little collection, wishing to provide for a year's cycle of Marian sequences, had insufficient items to hand; either because the new Marian sequences composed in the 13 th century in such enormous quantities had not yet become available, or because he was too far removed from the cultural centres where they were available.20 Because of the inconclusive nature of their evidence for present purposes, I have not here analyzed at length the collections cited in Table 4. At least one may perhaps say that concordances with such books as Arsenal 135, which has itself significant continental concordances, suggest that the repertory has come from the same milieu as the ordinary of mass collections. But for more specific pointers to the affiliations of W1's sequence collection we shall have to adopt a different approach.

\section{Variants}

By comparing variant readings in the text and music of the sequences we may hope to discover significant correspondences between $W 1$ and one or more of the sources cited above.

For this purpose it would be possible, though somewhat arduous, to allow weight to every variant down to the smallest ortho-graphic detail. Yet a moment's consideration occasions doubts as to the wisdom of such a policy. All variants may not be of equal significance. It seems desirable to attempt a rough division into at least two types of variant: (a) those which might have been perpetrated independently by more than one copyist or editor; (b) those significant enough to be unlikely to have occurred independentiy to more than one copyist or editor, thus possible evidence of a definite copying tradition. Clearly there is room for dis-agreement in the choice of variants which should count as 'significant'; but doubtful cases are usually, in my experience, a negligible proportion of those which may be isolated. 21

In group (a) I class such text variants as those where only one letter is involved, where an abbreviation has been expanded in different ways, where case ending or declen-sion differ, where word order is reversed: e.g. quam/quem, suam/suum, superat/superet, calcans/calcet, matremaue faciat secum participem / secumaue fatiat matrem participem. 
TABLE 4

SEQUENCES, W1 FASCICLE 11

$\times$ signifies concordance

* signifies an addition to the manuscript

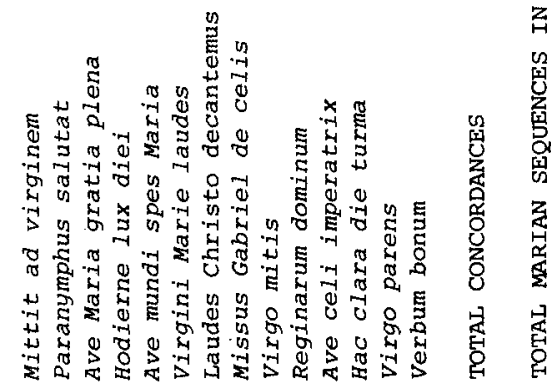

Paris Bibl. de l'Arsenal 135 (?London, late 13th c.)

London B.L. Add. 37519 (Oxford, 14th c.)

oxford Bodleian Lib. Lyell 9 (Breamore, late 13th c.)

oxford University Coll. 148 (Chichester, late 13th c.)

Oxford University Coll. 169 (Barking, 14th c.)

oxford Bodleian Lib. Lat.1it.b.5 (York diocese, 15th c.)

Cambridge St.John's Coll. D.27 (St.Mary's York, 15th c.)

Manchester John Rylands Lib. lat. 24 (Sarum, mid 13th c.)

London B.L. Lansdowne 462 (and most other Sarum sources)

Cambridge Univ.Lib. Add.710 (Sarum, early 14th c.)

London B.L. Add.11414 (Sarum, 15th c.)

Rouen Bibl.Mun. 277 (Rouen Cathedral, mid 13th c.)

Paris B.N. lat.904 (Rouen Cathedral, 13th c.)

Rouen Bibl.Mun. 276 (St.Ouen Rouen, 13th c.)

Limoges Bibl.Mun. 2 (Fontévrault, 14th c.)

Arras Bibl.Mun. 437 (St.Vaast Arras, 13th C.)

Douai Bibl. Mun. 114 (Marchiennes, 14th c.)

Douai Bibl.Mun. 124 (Anchin, 15-16th c.)

Cambrai Bibl.Mun. 32 (Maubeuge - PParis - late 13th c.)

Paris B.N. lat.17318 (and other mss. from St.Corneille Compiègne)

Paris B.N. lat.1107 (St.Denis, late 13th c.)

London B.L. Add. 38723 (Paris, late 13th c.)

London B.L. Add.16905 (Paris, late 13th C.)

London B.L. Harley 2891 (Ste.Chapelle Paris, 14th c.)

Bari San Nicola 1 (Paris, late 13th c.)

Assisi Bibl.Comunale 695 (?Paris, late 13th c. - three series)

London B.L. Add.23935 (Dominican, mid 13th c.)

Paris B.N. lat.14452 (St.Victor Paris, mid 13th c.)

Rouen Bibl.Mun. 249 (St.Laurent Eu, 14th c.)

printed missals:

Evreux (1497)

Lisieux (1504)

Coutances (1499)

Avranches (1505)

Arras (1491)

Liège (1485)

Thérouanne (1516)

Amiens (1487)

Beauvais (1514)

Châlons-sur-Marne (1489)

Senlis (1524)

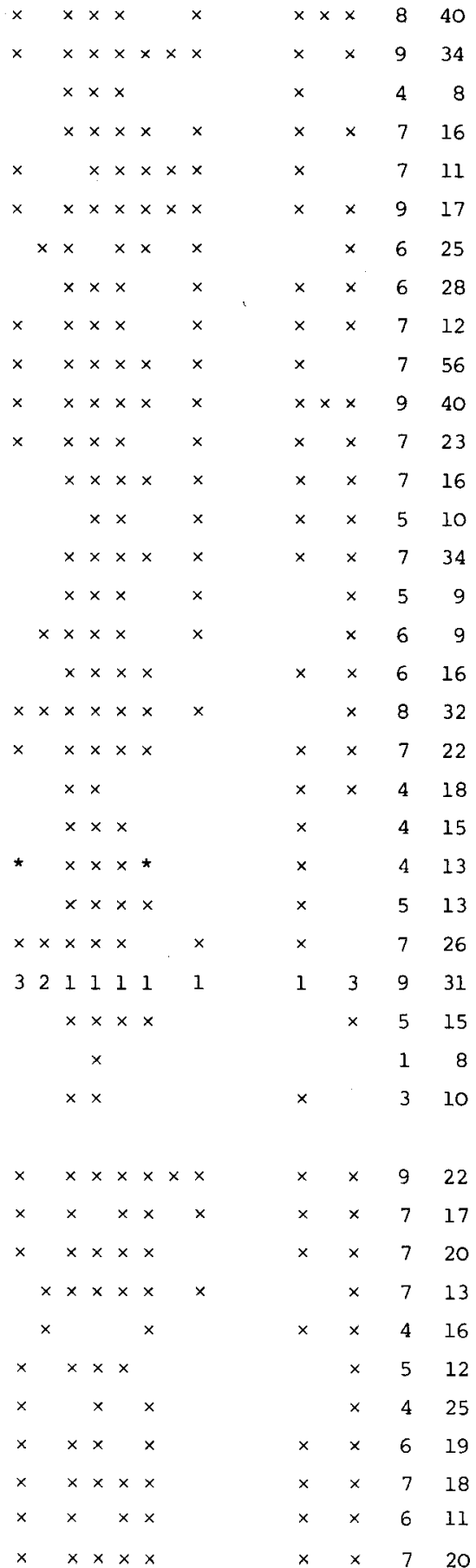


In group (a) I class such music variants as concern liquescents, passing or anticipatory notes, and differences in pitch which do not alter the direction of the melodic movement: e.g. f/ffliquescent, gf e d/g liquescent e d. The differences between the following six versions of the same phrase seem insignificant according to this reasoning:

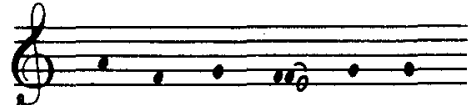

Arsenal

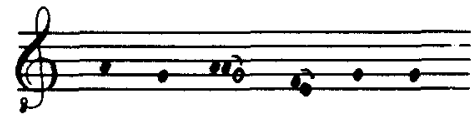

135
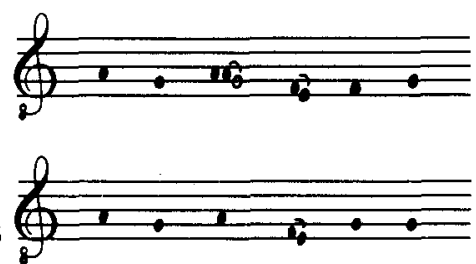

Oxford

Lat. 1 it.b.

Bari 1; Cambridge

710

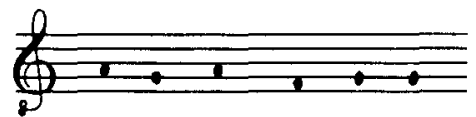

Assisi

695

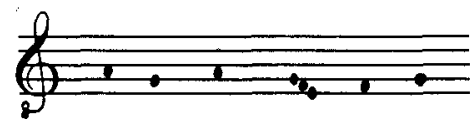

(A11 variants given so far are from Mittit ad virginem.)

Class (b) variants include added lines or parts of lines (or their omission), or the reversal of whole 1 ines; also cases where the appearance of a word is quite different even if the sense remains similar (but not cases where the appearance is hardly altered but the sense strongly altered, as in a grammatical error): e.g. domina/regina, obvia/valida (from Hodierne zux diei). An example of a variant where the direction of the melody is affected is the following (taken from Mittit ad virginem again):

W1;

Bari 1;

Oxford Lat.

lit.b. 5

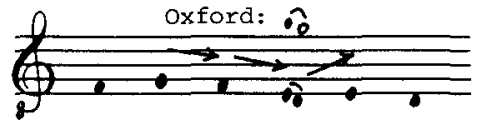

Assisi 695 . Cambridge 710 Rouen 277; Arsenal 135

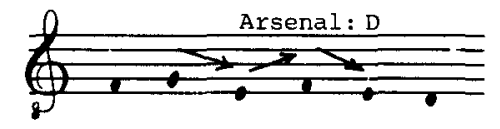

In the next example (next column), no less than seven versions significantly different from $W 1$ are to be found, in a line from $A v e$ mundi spes Maria.

I have chosen to regard as statistically neutral those variants which occur in one source only (as in the case of the text of Oxford Lat.1it.b.5 in the next example), since these merely 'distance' the source in question from all others, making groups and interrelationships between sources no easier to distinguish. I have counted such unique readings as equivalent to lacunae.
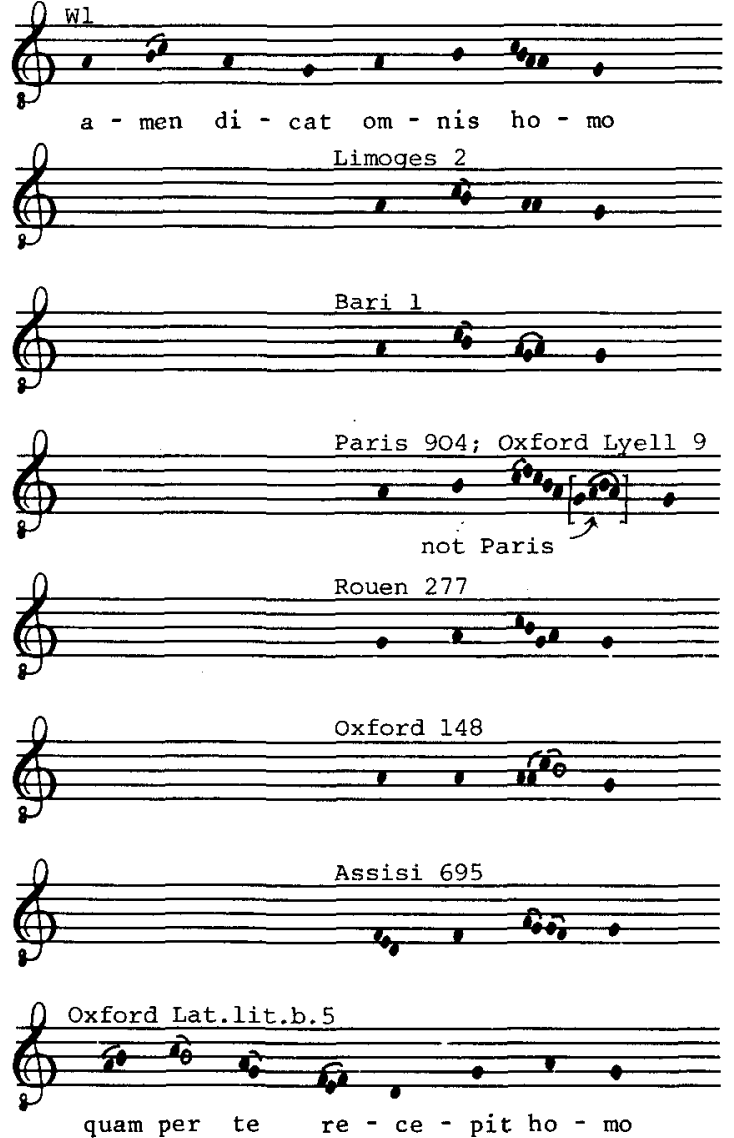

For only eight of the fourteen sequences in 1 are there two more sources with music with which W1 may be compared. One of them, Virgini Marie laudes, pro-vided no significant variants at all. In fact, for only two individual sequences, Ave Maria gratia plena and Ave mundi spes Maria, were there enough variants for a pattern of manuscript affiliations to emerge. In Ave Maria gratia plena W1 belongs to a 'central' group with the books from Salisbury (Manchester lat.24), Chichester (Oxford 148), Dublin (Cambridge 710), Bari and Rouen (Paris 904, Rouen 277), while other books are less firmly allied to only one or two of these sources and are not related to each other. For Ave mundi spes Maria the 'central' group is W1, Salisbury, ?London (Arsenal 135), Dublin, Breamore (Oxford

Lye11 9) and York (Oxford Lat.lit.b.5). Table 5 gives the number of readings common to $W 1$ and the other sources for each sequence separately; and from this it is clear that different patterns of agreements are present for each sequence. Table 6 , which gives the cumulative totals of agreements between all the sources for all sequences combined, should therefore be regarded with some caution. The figures for what they are worth, are translated into percentages and then given graphic representation in Diagram 1, drawn up by a method first used for musicological purposes by the monks of Solesmes.22

That the results of this survey are not entirely arbitrary seems to be confirmed by the close proximity in Diagram 1 of the two manuscripts from Rouen (Paris 904 and Rouen 277), and the almost equally close alliance between manuscripts in the main English group. Although $W 1$ is certainly, on this evidence, part of the mainstream 
TABLE 5

POINTS OF VARIANCE

NUMBER OF AGREEMENTS, W1 AND OTHER SOURCES

For each entry, the top figure gives the number of agreements between $W 1$ and the ms. in question; the lower figure gives the total of points of variance isolated for the sequence, minus lacunae.

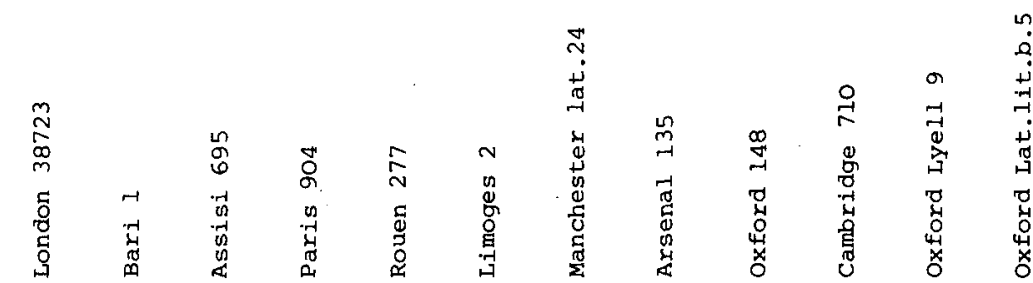

Mittit ad virginem

Ave Maria gratia plena

$\frac{3}{6} \quad \frac{3}{6} \quad \frac{1}{6}$

$\frac{2}{6} \quad \frac{1}{6} \quad \frac{2}{6}$

$\begin{array}{llllllllllll}\frac{8}{17} & \frac{12}{18} & \frac{8}{18} & \frac{9}{18} & \frac{7}{18} & \frac{8}{17} & \frac{9}{18} & \frac{13}{18} & \frac{14}{18} & \frac{11}{18} & \frac{13}{18} & \frac{10}{18}\end{array}$

Hodierne lux diei

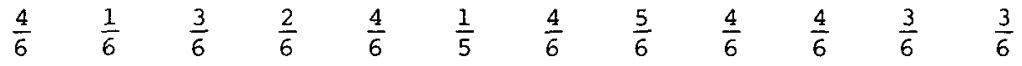

Ave mundi spes Maria

$\frac{7}{13} \quad \frac{8}{12} \quad \frac{4}{12} \quad \frac{7}{12} \quad \frac{9}{12} \quad \frac{4}{12} \quad \frac{11}{13}, \frac{11}{13} \quad \frac{8}{12} \quad \frac{11}{13} \quad \frac{10}{12} \quad \frac{12}{13}$

Missus Gabriel de celis

Hac clara die turma

Verbum bonum et suave

TOTAL

PERCENTAGE AGREEMENT WITH WI

$$
\begin{array}{lllllllllll}
\frac{2}{5} & \frac{3}{5} & \frac{1}{5} & \frac{1}{5} & \frac{3}{4} & \frac{5}{5} & \frac{2}{4} & \frac{2}{4} & \frac{4}{5} & \frac{1}{5}
\end{array}
$$$$
\begin{array}{llllllllllll}
\frac{3}{3} & \frac{1}{3} & \frac{1}{3} & \frac{1}{3} & \frac{1}{3} & \frac{1}{3} & \frac{2}{3} & \frac{2}{3} & \frac{1}{3} & \frac{3}{3} & \frac{2}{3} & \frac{3}{3}
\end{array}
$$$$
\begin{array}{lllllllllll}
\frac{2}{2} & \frac{2}{2} & \frac{1}{2} & \frac{1}{2} & \frac{2}{2} & \frac{2}{2} & \frac{1}{2} & \frac{1}{2} & \frac{1}{2} & \frac{1}{2} & \frac{2}{2}
\end{array}
$$

$\begin{array}{llllllllllll}\frac{22}{38} & \frac{29}{52} & \frac{24}{51} & \frac{21}{46} & \frac{24}{52} & \frac{19}{43} & \frac{33}{47} & \frac{36}{52} & \frac{30}{45} & \frac{36}{53} & \frac{30}{41} & \frac{33}{53}\end{array}$

$\begin{array}{llllllllllll}58 & 56 & 47 & 46 & 46 & 44 & 70 & 69 & 67 & 68 & 73 & 62\end{array}$

DIAGRAM 1

INTERRELATIONSHIPS BETWEEN SOURCES, THE SEVEN MARIAN SEQUENCES

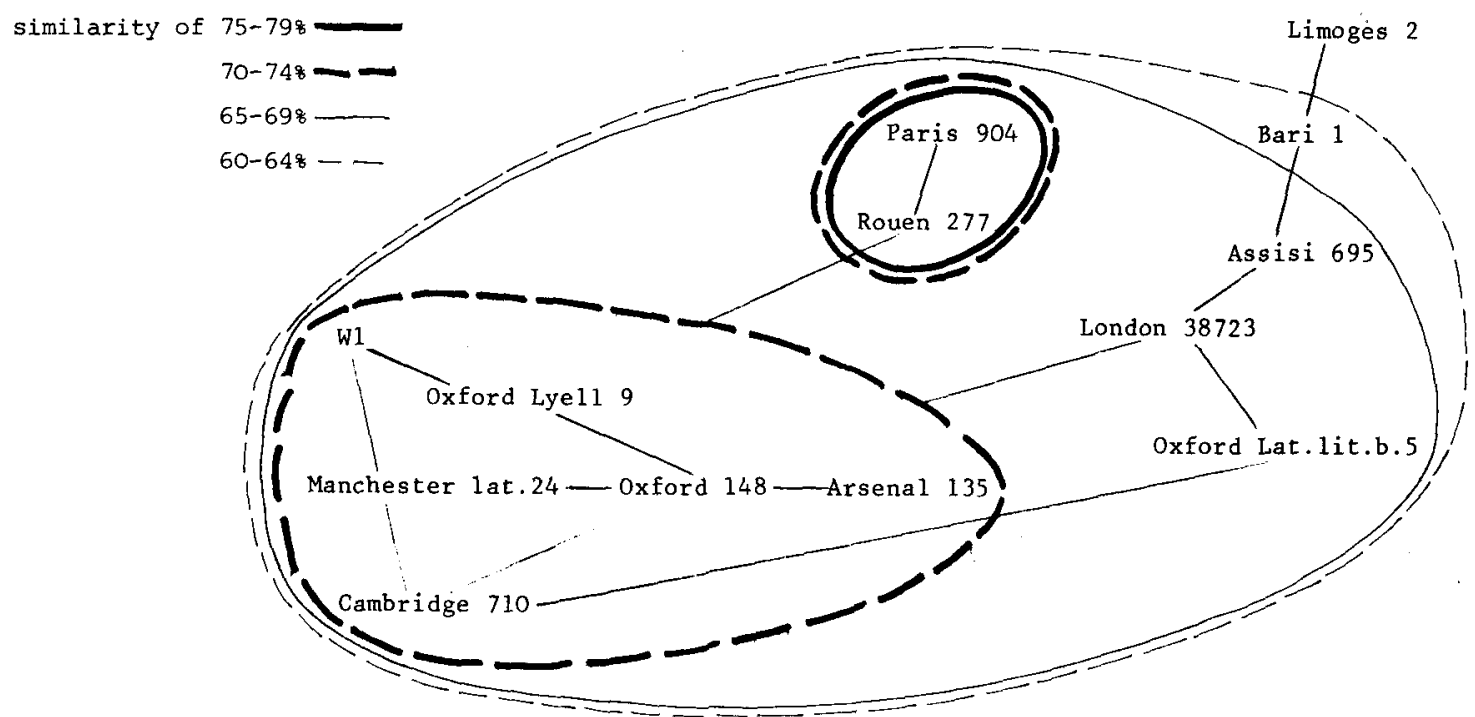


TABLE 6

POINTS OF VARIANCE

NUMBER OF AGREEMENTS, ALL SOURCES

The number of agreements between sources is given first,

above the number of points of variance available. The

percentage agreement between sources is given in italic.

WI

London 38723

Bari 1

Assisi 695

Paris 904

Rouen 277

Limoges 2

Manchester lat.24

Arsenal 135

Oxford 148

Cambridge 710

Oxford LyelI 9

Oxford Lat.1it.b.5

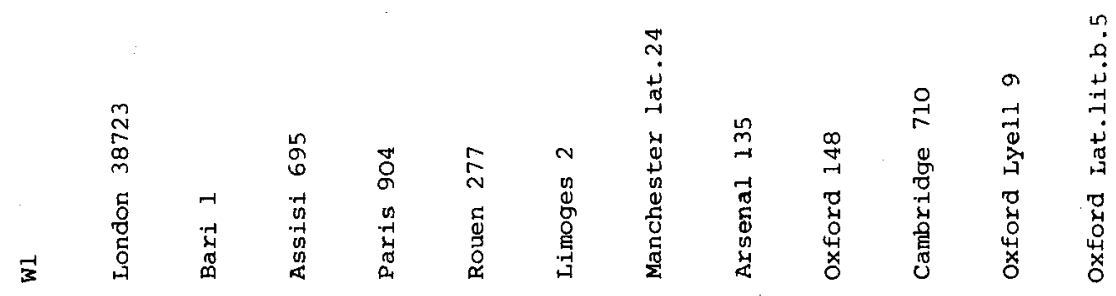

$\frac{22}{38} 58 \quad \frac{29}{52} 56 \quad \frac{24}{51} 47 \quad \frac{21}{46} 46 \quad \frac{24}{52} 46 \quad \frac{19}{43} 44 \quad \frac{33}{47} 70 \quad \frac{36}{52} 69 \quad \frac{30}{45} 67 \quad \frac{36}{53} 68 \quad \frac{30}{41} 73 \quad \frac{33}{53} 62$

$58 \quad \frac{22}{38} 58 \quad \frac{24}{37} 65 \quad \frac{21}{38} 55 \quad \frac{25}{38} 66 \quad \frac{14}{35} 40 \quad \frac{26}{39} 67 \quad \frac{26}{39} 67 \quad \frac{23}{39} 59 \quad \frac{22}{39} 56 \quad \frac{21}{39} 54 \quad \frac{25}{38} 66$

$56 \quad 58 \quad \frac{32}{52} 62 \quad \frac{28}{48} 58 \quad \frac{30}{54} 56 \quad \frac{24}{43} 56 \quad \frac{24}{48} 50 \quad \frac{25}{54} 47 \quad \frac{25}{46} 54 \quad \frac{30}{54} 56 \quad \frac{26}{41} 63 \quad \frac{29}{53} 55$

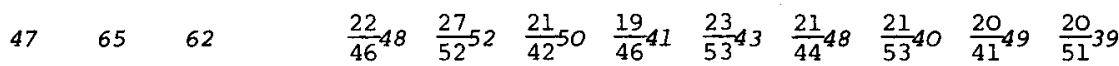

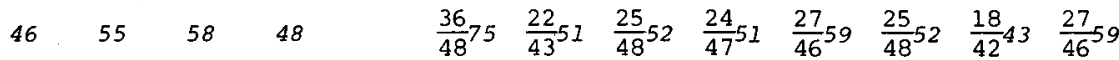

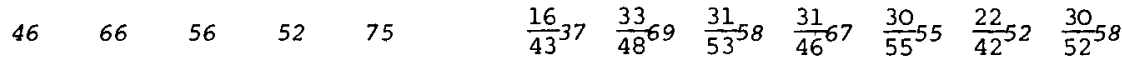

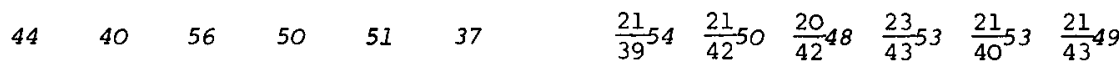

$\begin{array}{llllllllllll}70 & 67 & 50 & 41 & 52 & 69 & 54 & \frac{32}{48} 67 & \frac{32}{46} 70 & \frac{36}{49} 73 & \frac{27}{42} 64 & \frac{30}{47} 64\end{array}$

$\begin{array}{llllllllllll}69 & 67 & 47 & 43 & 51 & 58 & 50 & 67 & \frac{33}{45} 73 & \frac{37}{55} 67 & \frac{27}{42} 64 & \frac{34}{47} 64\end{array}$

$\begin{array}{llllllllllll}67 & 59 & 54 & 48 & 59 & 67 & 48 & 70 & 73 & \frac{33}{46} 72 & \frac{29}{41} 71 & \frac{27}{45} 60\end{array}$

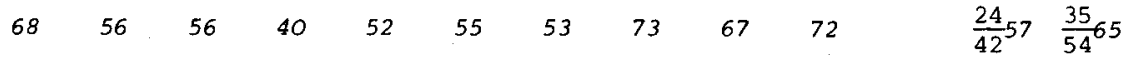

$\begin{array}{llllllllllll}73 & 54 & 63 & 49 & 43 & 52 & 53 & 64 & 64 & 71 & 57 & \frac{25}{41} 61\end{array}$

$\begin{array}{llllllllllll}62 & 66 & 55 & 39 & 59 & 58 & 49 & 64 & 64 & 60 & 65 & 61\end{array}$ 
English tradition, it is worth noting that only $11 \%$ separates the Breamore manuscript (Oxford Lyel1 9) from the York one (Oxford Lat.1it.b.5) in terms of 'closeness' to W1. If different cut-off points had been used in the construction of Diagram 1, the result might have looked much less decisive! Since Oxford Lyell 9 has only five of the sequences compared, its scores are in any case less reliable. At least it may be said that no definite support has emerged for the idea that $\mathrm{St}$.Andrews, repre- sented by W1, might have acquired parts of its liturgical repertory from York.

\section{Polyphonic sequences}

The fortunate survival of the large early-13th-century Parisian repertory of polyphonic responsories, graduals and alleluias has tended to overshadow the existence of polyphonic movements of the ordinary of mass, and polyphonic sequences, from this period. 23 The latter are of course far more modest in musical style than the former, and no doubt less prized in their day, as in ours. Yet to suppose they were not well-known in the centres where the more ambitious polyphonic reper-tories were performed would go in the face of historical probability and of the evidence of the sources themselves. The repertories of Winchester, the Aquitanian and related sources of the 12 th century, all the main 'peripheral' sources of the 13 th century (the 'Worcester Fragments', the 'Las Huelgas' manuscript, the Tortosa books, Munich Bayerische Staatsbibl. lat.5539, London British Lib. Add.27630) include these genres. Polyphonic sequences in particular abound. Among the sources I have cited above, Assisi 695 has four, and the same four also occur in Cambrai Bibl. Municipale 32 (from Maubeuge in Hainault); Limoges 2 has two, and Rouen 277 has one. 2 Over 40 polyphonic pieces with the repeatverse structure of the sequence survive in English sources - whether all functioned liturgically as sequences after the alleluia at mass is of course open to question, since such pieces are known also as tract, offertory or hymn substitutes, among other things.

We have lost what may have been one of the largest repertories of English poly-phonic sequences. It seems to me to be worth speculating as to whether the last 48 titles of the index of lost polyphony in London British Lib. Harley 978 might not refer to sequences. 31 of the titles suggest the commonest 13th-century sequence metres (12 are seven-syllable lines, masculine end; 14 are eight-syllable, feminine end; 5 are eight-syllable, masculine end). They seem almost exclusively designed for liturgical use $;^{25}$ hardly more than three suggest moral or didactic poetry. Five are the first lines of known sequences: the very common Ascensiontide sequence Rex omnipotens and the four Marian pieces Gaude virgo concipiens (in Cambridge 710), Salve mater salvatoris (Arsenal 135 and everywhere in the neighbourhood of Paris), Gaude virgo mater Christi (London 11414, London 25588 and Bari 1), and Ave Maria gratia plena. It would of course be easy to overstate the case; there are other possibilities; but this one seems worth considering.

It will not do to say that sequences were omitted from the main sources of Parisian polyphony because they were 'para-liturgical' in some way. The secular Latin conductus in those sources have no liturgical propriety at a11. The reason must be a musical one. After the sequences in the Aquitanian sources which are set in melis-matic organum, no further attempt seems to have been made to set sequences in anything but simple contrary-motion discant Pieces in this style were generally too humble for inclusion in the sources of Notre-Dame organum. That did not prevent some conductus in simple style from coming into the collections on the coat-tails, as it were, of the larger, partially melis-matic conductus. (And in W2 they brought with them a sequence, Verbum bonum ${ }^{26}$ ). But for sequences, and ordinary of mass movements, the way seems normally to have been barred. According to this hypothesis W1 is the manuscript which best represents, in one source, the range of genres of sacred polyphony used in a major church in the first half of the 13 th century.

\section{Notes}

1 M.Lltolf: Die mehrstimmigen ordinarium MissaeSatze vom ausgehenden 11. bis zur Wende des 13. zum 14. Jahrhundert (Berne, 1970); $R$. Flotzinger: 'Beobachtungen zur Notre-Dame Hand-schrift W1 und ihrem 1I. Faszikel', Mitteil-ungen der Kommission für Musikforschung: Anzeiger der philosophisch-historischen Klasse der Österreichischen Akademie der Wissenschaften, cv/19 (Vienna, 1968, pp.245-262; E.H.Roesner: 'The origins of Wl', Journal of the American Musicological Society, 29 (1976), pp.337-81.

2 The six troped Sanctus and six troped Agnus at the end of fascicle 10, all monophonic, are mostly unique, or have only continental concordances, and are thus, as Roesner rightly says (p.375, n.181), part of a tradition diff-erent from that of the other ordinaxy of mass chants. The unusual concordances are with St. Gallen, stiftsbibl., 383 (and thence into st. Gallen 546), which probably reflects a Parisian, or at least North French, exemplar, and with Assisi 695 (Agnus trope Vulnere quorum, f.50r, incorrectly ascribed to mel.267 in Schildbach's catalogue), again within a Parisian orbit of some sort.

3 M.Landwehr-Melnicki: Das einstimmige Kyrie des lateinischen Mittelalters (Diss., Erlangen, 1954) D.Bosse: Untersuchung einstimmiger mittelalter-licher Melodien zum 'Gloria in excelsis' (Diss., Erlangen, 1954); P.J.Thannabaur: Das einstimmige Sanctus der römischen Messe in der handschriftlichen Überlieferung des 11.-16. Jahrhunderts, Erlanger Arbeiten zur Musikwissenschaft, i, herausgegeben von Bruno Stäblein (Munich, 1962); M. Schildbach: Das einstimmige Agnus Dei und seine handschrift-liche Überlieferung vom 10. bis zum 16. Jahr-hundert (Diss., Erlangen, 1967).

My own catalogue will be published shortly in the Research Chronicle of the Royal Musical Association.

The chief merit of Analecta Liturgica, apart from its editions of texts, is that it lists the complete repertory of each source it covers: $E$. Misset and W.H.J.Weale: Analecta Liturgica, II; Thesaurus Humnologicus, i-ii (Bruges, 1888-92). For easy reference to the various editions of sequences in Analecta Hymnica, see M.Lütolf, ed. : Analecta Hymnica - Register (Berne and Munich, 1978)

4 D.Hiley: 'The Norman chant traditions - Normandy, Britain, Sicily', Proceedings of the Royal Musical Association, 107 (1980-81), Diagram 4 on p.28. 
5 Oxford, Bodleian Lib., Bodley 775 (two collections: late loth c. and late 11 th c., from winchester); Cambridge, Corpus Christi Coll., 473 (1ate loth c., from Winchester); Durham, University Lib., Cosin V.V.6 (late 11th c., from Christ-church, Canterbury); Oxford, Bodleian Lib., Laud misc. 358, and London, British Lib. , Royal 2.B.IV (both late 12 th $\mathrm{c}$., from St. Albans).

6 Paris, Bibl.Nationale, lat.905 (15th c.); and Paris, Bibl.Nationale, lat.904, whose ordinary of mass collection is an addition of the 15 th century.

7 For instance, Paris, Bibl.Nationale, lat.830, 1112,861 , in Melnicki's catalogue, etc.; also London, British Lib., Add. 38723 and 16905.

8 In my own catalogue I give melodies not in Melnicki, etc., as $165 \mathrm{a}, 165 \mathrm{~b}$, etc. Tropes not in Melnicki, etc., are given a number in brackets, e.g. Kyrie $48 \mathrm{tr}$. (12) Kyrie salve semperque. For Gloria tropes the numbering is based on the alphabetical list in K.Rönnau: Die Tropen zum Gloria in excelsis Deo, unter besonderer Berücksichtigung des Repertoires der St.Martial-Handschriften (Wiesbaden, 1967).

9 Primarily Paris, Bibl. Nationale, lat.14452, in Melnicki, etc. Also Rouen, Bibl. Municipale, 249, from St.Laurent at Eu; and Bristol, Central Lib., 2, from St.Augustine's, Bristol (incipits for Kyries and Glorias).

10 I know of the contents of Bari 88 (and 85) only from Melnicki, etc. Information on the establish-ment of Parisian use at Bari is given in R.-J. Hesbert: Le prosaire de la Sainte-Chapelle, Monumenta musicae sacrae, i (Mâcon, 1952).

11 Edition of the text in U.Chevalier: Sacramentaire et martyrologe de 1'abbaye de Saint-Remy. Mar-tyrologe, Calendrier, Ordinaires et Prosaire de la métropole de Reims (VIIIe-XIIIe siècle, publiés d'après les manuscrits de paris, Londres, Reims et Assise, Bibliothèque liturgique, vii (Paris, 1900), pp.358-394. The discussion of the manuscript, ibid. pp.L-LXXI, is largely by G. de Manteyer. An inaccurate inventory and account of the manuscript is given in A. Seay: 'Le manuscrit 695 de la bibliothèque communale d'Assise', Revue de Musicologie, 39 (1957), pp. 10-35. See also H.Husmann in RISM, B/V/I (Munich and Duisburg, 1964), pp.167-9.

12 See my forthcoming paper, 'Reconstructing the pre-Victorine Paris sequence repertory'. Husmann, op.cit., p.167, speaks only of Reims variant readings, but in most of the first-epoch sequences which are not obvious borrowings from the Reims repertory, Assisi 695 has Paris melodic and text variants.

13 This lessens the force of Roesner's comments, op.cit. (see n.1), p.375, where it is assumed that Arsenal 135 presents an ordinary of mass collection which can somehow be called 'Sarum'.

14 Melodies 110 and 162 should be credited to ms. E4, not E3. At melody 171 there appears to have been another error in the original type-script, now corrected.

15 Paris, Bibl. de 1'Arsenal, 135, f.288v: Agnus 114 tr.36 Factus homo, tr. (34a) Eructavit cor meum, tr. (37a) Flos de flore pia.

16 C.Hohler: 'Reflections on some manuscripts containing 13 th-century English polyphony' , Journal of the Plainsong \& Mediaeval Music Society, I (1978), po.25-8, the manuscript referred to as 'Sarum $A$ ', after $J$.Wickham Legg's edition of The Sarum Missal (oxford, 1916). Apart from the arguments advanced by Hohler, the kalendar includes St.Erkenwald (Earconwald), the 7 th-century bishop of London whose medieval shrine was at St.Paul's cathedral.

17 It is just possible that the Kyrie trope incipit Kyrie pater alme may refer to the piece added on f.32v of Madrid, Bibl.Nacional, 289, with a unique melody and the trope $O$ pater alme.

18 Text edition in L.McLachlan and J.B.L.Tolhurst: The ordinal and customary of the Abbey of $S t$. Mary, York, Henry Bradshaw Society, 73, 75 and 84 (London, 1936-51). The Marian votive section ("Missa familiaris, sive de domina...", ff.5ov$51 r)$ is edited pp. $57 \mathrm{f}$

19 I omit from further consideration Ave Maria gratia plena viris invia (f.209/192r), which, though probably intended to serve as a sequence is composed in the form of a five-strophe song.

20 A Marian collection which gives a somewhat similar impression is that following the main series of sequences in Manchester, John Rylands Library, lat.24, a Sarum noted missal probably prepared at Salisbury in the mid 13 th century for Exeter (see J.W.Legg: The Sarum Missal, Oxford, 1916, and A.Hollaender: 'The Sarum Illuminator and his school', Wiltshire Archaeological and Natural History Magazine, i, 1942-4, pp.230-62). Here we find 18 Marian sequences, 8 in firstepoch style (of which no less than 4 are unica, despite the late date of the manuscript), and 10 in the new rhyming style (only one unicum). Here again one feels that the demand for Marian pieces outstripped the supply of sequences in modern style.

21 For a similar survey, see Chapter 13 (pp.343-75) of my thesis: The liturgical music of Norman Sicily: a study centred on manuscripts 288,289 19421 and Vitrina 20-4 of the Biblioteca Nacional, Madrid (University of London, 1981). Here 275 points of variance were isolated from 23 sequences in 23 sources in order to trace the affiliations of sequence sources in Sicily, North France and Britain. (The results are also summarized in the article cited in n.4, Diagram 6 on p.33. Certain differences in treatment are necessary as between a 'first-epoch' sequence repertory and a 13 th-century one. In the latter the convention of one note per syllable no longer has much force, cadence formulae are more varied, and a new vocabulary of ornamental figures has evolved.

22 Le Graduel Romain, IV/i: Le groupement des manu-scrits (Solesmes, 1960). Despite the arbitrary optical effects which such diagrams may produce, they are a useful way of enabling one to grasp quickly the broad implications of a mass of statistical data. To construct the diagram, the sources related in the closest degree are written down, and a line is drawn between them; then a circle is dxawn round any sources linked by lines. The process is repeated for each lower degree of proximity. Not all sources within the same circle will necessarily be linked to the same degree - it is the joining lines which indicate the relationship which brings a source into a particular circle.

23 But Lütolf's book (see n.l above) does much to right the balance so far as ordinary of mass compositions are concerned.

24 Edited.by W.Dalglish: 'A polyphonic sequence from Rouen', Music \& Letters, 59 (1978), pp. 17-18. The correspondence Dalglish suggests with a sequence in Arsenal 135 does not, given the stylistic conventions in operation, seem very compelling.

25 Nine might be described as generally scriptural/ liturgical; nine are for our Lord, twelve (or more) for the Blessed Virgin. There are two for st. Katherine, two possibly for St.Peter, three for saints, one for confessors, three for martyrs, two (or more) for virgins, one for Ascension.

26 Wolfenbiuttel, Herzog-August-Bibliothek, Helmstedt 1099 (Heinemann catalogue 1206), f.l4lv. Oddly enough, it includes the only example I have noticed in $\mathrm{W} 2$ of 'Rautenternaria', the climacus written $\beta$, common in England (although also known in North France). 


\section{APPENDIX}

SUMMARY OF THE CONTENTS OF W1

$/ /$ indicates missing leaves. * indicates additions to first layer of parisian polyphony

\begin{tabular}{|c|c|c|c|c|}
\hline \multirow[t]{2}{*}{ Fascicle } & \multirow[t]{2}{*}{ Contents } & \multirow[t]{2}{*}{ Gathering } & \multicolumn{2}{|c|}{ Foliation } \\
\hline & & & old & New \\
\hline 1 & organa and clausula a 4 & 1 & //iii-vi// & $1-4$ \\
\hline 2 & organa and conductus a 3 & 2 & $i x-x v i$ & $5-12$ \\
\hline 3 & $\begin{array}{l}\text { organa a2 (for office), organa a2 (mostly for } \\
\text { office)*, Sanctus a2* }\end{array}$ & 3 & xvil-xxiv & $13-20$ \\
\hline \multirow[t]{3}{*}{4} & organa a2 (for Mass) & 4 & $\begin{array}{c}x x v-x x i x \\
30-32\end{array}$ & $21-28$ \\
\hline & & 5 & $33-35 / / 38-40$ & $29-34$ \\
\hline & & 6 & $41-48$ & $35-42$ \\
\hline 5 & clausulas a2 & 7 & $49-50 / / 53-4$ & $43-46$ \\
\hline 6 & clausulas a2*, conductus a $2^{\star}$ & 8 & $55-62$ & $47-54$ \\
\hline 7 & organa a $3^{*}$ & 9 & $\begin{array}{l}63-68 \\
68 \mathrm{bis}, 69\end{array}$ & $55-62$ \\
\hline \multirow[t]{3}{*}{8} & conductus a3, organa a 3 , organum a $3^{*}$, clausula a3*, & 10 & $70-78$ & $63-71$ \\
\hline & Sanctus and Agnus a $3^{*}$ & 11 & $79-82 / / 85-86$ & $72-77$ \\
\hline & & 12 & $87-94$ & $78-85$ \\
\hline \multirow[t]{10}{*}{9} & conductus a 3 and a2, organa a2, Agnus a2* & 13 & $95-102$ & $86-93$ \\
\hline & & 14 & $103-110$ & $94-101$ \\
\hline & . & 15 & $111-120$ & $102-111$ \\
\hline & & 16 & $121-128$ & $112-119$ \\
\hline & & 17 & $129-136$ & $120-127$ \\
\hline & & 18 & $137-144$ & $128-135$ \\
\hline & & 19 & $145-152$ & $136-143$ \\
\hline & & 20 & $153-160$ & $144-151$ \\
\hline & & 21 & $161-168$ & $152-159$ \\
\hline & & 22 & $169-176 / /$ & $160-167$ \\
\hline 10 & conductus al, Sanctus and Agnus al* & 23 & $/ / 185-192$ & $168-175$ \\
\hline \multirow[t]{3}{*}{11} & $\begin{array}{l}\text { Kyries, Gloria, alleluias, tracts, sequences, } \\
\text { offertories, Sanctus and Agnus a }{ }^{*}\end{array}$ & 24 & $193-200$ & $176-183$ \\
\hline & & 25 & $201-208$ & $184-191$ \\
\hline & & 26 & $209-214$ & $192-197$ \\
\hline
\end{tabular}

